ISSN: 2302-8556

E-Jurnal Akuntansi Universitas Udayana

Vol.26.2.Februari (2019): 1048-1074

DOI: https://doi.org/10.24843/EJA.2019.v26.i02.p08

\title{
Pengaruh Financial Distress, Ukuran Perusahaan, dan Audit Delay Terhadap Pergantian Auditor
}

\author{
I Dewa Ayu Adelia Pratiwi ${ }^{1}$ \\ Ketut Muliartha $\mathbf{R M}^{2}$ \\ ${ }^{1,2}$ Fakultas Ekonomi dan Bisnis Universitas Udayana (Unud), Bali, Indonesia \\ e-mail: adeliapratiw@yahoo.com
}

\begin{abstract}
ABSTRAK
Pergantian auditor secara sukarela dapat terjadi karena adanya permasalahan baik dari auditor maupun perusahaan itu sendiri. Pergantian auditor secara sukarela akan menimbulkan kecurigaan dari pemegang saham. Penelitian ini bertujuan untuk meneliti pengaruh financial distress, ukuran perusahaan, dan audit delay terhadap pergantian auditor. Populasi pada penelitian ini adalah perusahaan manufaktur yang terdaftar di Bursa Efek Indonesia tahun 2015-2017. Metode penentuan sampel menggunakan metode non probability sampling dengan teknik purposive sampling dan diperoleh 168 pengamatan. Penelitian ini menggunakan analisis regresi logistik sebagai teknik analisis data. Hasil dari penelitian ini menunjukkan bahwa financial distress tidak berpengaruh terhadap pergantian auditor, ukuran perusahaan berpengaruh positif terhadap pergantian auditor, dan audit delay tidak berpengaruh terhadap pergantian auditor.
\end{abstract}

Kata kunci: Financial distress, ukuran perusahaan, audit delay, pergantian auditor.

\begin{abstract}
Voluntary auditor switching can occur because of problems from both auditor and the company itself. Voluntary auditor switching can arousing suspicion from investor. This study aims to obtain empirical evidence of the effect of financial distress, company size, and audit delay to auditor switching. The population of this research is manufacturing company listed on the Indonesia Stock Exchange in 2015-2017. The method of determining sample using non probability sampling method with purposive sampling technique and obtained 168 observations. This study using logistic regression analysis as data analysis techniques. The result of analysis shows that financial distress does not infulence auditor switching, company size positively influence auditor switching and audit delay does not influence auditor switching.
\end{abstract}

Keyword: Financial distress, company size, audit delay, auditor switching.

\section{PENDAHULUAN}

Perusahaan go public memiliki kewajiban untuk menerbitkan laporan keuangannya. Menurut Widyanti (2016), laporan keuangan dijelaskan sebagai alat untuk memberikan informasi keuangan kepada pihak eksternal perusahaan yang disajikan oleh manajemen perusahaan dan penting untuk menyajikan laporan keuangan yang terpercaya karena akan berpengaruh pada pengambilan keputusan 
yang dilakukan stakeholder. Oleh karena itu, independensi auditor merupakan faktor penting dalam menghasilkan laporan keuangan terpercaya yang menyajikan keadaan perusahaan yang sesungguhnya.

Hubungan kerja yang lama antara auditor dengan klien dapat mempengaruhi objektivitas dan independensi auditor dalam mengaudit laporan keuangan perusahaan. Hal ini juga dapat dilihat dari kasus Enron dan KAP Arthur Anderson pada tahun 2001, dimana KAP Arthur Anderson yang merupakan salah satu KAP besar yang termasuk ke dalam jajaran Big Five, tidak dapat mempertahankan independensinya dengan terlibat dalam kecurangan yang dilakukan oleh Enron, yang merupakan klien dari KAP Arthur Anderson (Abidin et al., 2016). Dengan adanya kasus ini mengakibatkan lahirmya Sarbanes Oxley Act (SOX) yang diterapkan dalam berbagai negara dengan menerapkan pergantian auditor secara wajib untuk meningkatkan pengawasan terhadap auditor (Khasanah dan Nahumury, 2013). Peraturan mengenai pergantian auditor di Indonesia diatur dalam Peraturan Pemerintah (PP) Nomor 20 Tahun 2015 tentang Praktik Akuntan Publik yang menyatakan bahwa perusahaan wajib melakukan pergantian auditor setelah masa perikatan paling lama 5 tahun berturut-turut dan perusahaan dapat melakukan perikatan kembali dengan auditor yang sama setelah 2 tahun buku berturut-turut tidak dalam masa perikatan dengan auditor tersebut. Peraturan ini menggantikan Peraturan Menteri Keuangan Republik Indonesia Nomor 17/PMK.01/2008 yang mengatur perusahaan wajib melakukan pergantian auditor setelah 6 tahun beturut-turut diaudit oleh KAP yang sama dan wajib melakukan 
pergantian auditor setelah 3 tahun berturut-turut diaudit oleh auditor atau akuntan publik yang sama.

Selain pergantian auditor secara wajib, terdapat juga pergantian auditor secara sukarela (Sumadi, 2011). Pergantian secara wajib dilakukan karena peraturan yang mewajibkan pergantian tersebut. Namun, pergantian secara sukarela dilakukan karena adanya permasalahan baik dari auditor maupun perusahaan itu sendiri (Robbitasari, 2013). Blouin et al. (2007) mengatakan bahwa pergantian auditor yang dilakukan oleh perusahaan bertujuan untuk memperbaiki sistem pengawasan. Namun, pergantian auditor secara sukarela ini akan menimbulkan kecurigaan dari pemegang saham sehingga faktor dilakukannya pergantian auditor secara sukarela ini penting untuk diketahui (Sinarwati, 2010).

Pergantian auditor dipengaruhi oleh beberapa faktor, salah satunya adalah financial distress yang merupakan keadaan perusahaan yang mengalami kesulitan dalam keuangan maupun keadaan perusahaan yang tidak sehat sehingga dikhawatirkan akan mengalami kebangkrutan (Sabeni dan Dwiyanti, 2014). Kondisi keuangan yang seperti ini cenderung mendorong perusahaan untuk melakukan pergantian auditor dengan auditor yang memiliki independensi yang tinggi untuk mendapatkan kepercayaan pemegang saham dan kreditur (Pradhana, 2015). Selain itu, pergantian auditor dapat dilakukan karena biaya audit yang dibebankan oleh auditor tidak mampu ditanggung oleh perusahaan karena perusahaan sedang mengalami financial distress (Sulistiarini dan Sudarno, 2012). 
I Dewa Ayu Adelia Pratiwi dan Ketut Muliartha RM. Pengaruh...

Hasil penelitian yang dilakukan oleh Nasser et al. (2006) dan Sabeni dan Dwiyanti (2014), dimana financial distress ditemukan berpengaruh positif terhadap pergantian auditor. Sebaliknya, penelitian yang dilakukan Chadegani et al. (2011), Ali (2015), Pradhana (2015) dan Kusrina (2008) menemukan bahwa financial distress tidak berpengaruh terhadap pergantian auditor.

Variabel lain yang digunakan adalah ukuran perusahaan yaitu besar kecilnya perusahaan yang dapat diukur dari keadaan keuangan perusahaan tersebut (Pradhana, 2015). Kristiawan (2017) mengatakan bahwa ukuran perusahaan dapat mencerminkan aktivitas dari suatu perusahaan. Ukuran perusahaan yang meningkat akan menyebabkan pemilik sebagai principal kesulitan dalam memantau tindakan manajer sebagai agent, yang mendorong manajemen cenderung untuk melakukan pergantian auditor dengan auditor yang lebih besar dan memiliki independensi tinggi karena auditor yang lebih besar dianggap lebih mampu menjembatani kebutuhan principal dan agent.

Penelitian terdahulu yang dilakukan oleh Sinason et al. (2001), Fitriani (2014), Gharibi dan Geraeely (2016), Lestari dan Nuryatno (2018) menemukan bahwa ukuran perusahaan berpengaruh secara signifikan terhadap pergantian auditor. Namun dalam penelitian yang dilakukan oleh Widiawan (2011), Pradhana (2015), dan Kristiawan (2017) menemukan bahwa ukuran perusahaan tidak berpengaruh terhadap pergantian auditor.

Salah satu karakteristik kualitatif yang harus dimiliki oleh suatu laporan keuangan yaitu relevansi dimana terdapat komponen ketepatan waktu (timeliness) yang akan meningkatkan manfaat laporan keuangan bagi para pengguna laporan 
keuangan (Ika S., 2014). Oleh karena itu, semakin lama tersedianya laporan keuangan maka manfaat laporan keuangan tersebut bagi para pengguna laporan keuangan akan berkurang. Akan tetapi agar laporan keuangan dapat dipercaya oleh para pengguna laporan keuangan perlu dilakukan audit oleh auditor eksternal terhadap laporan keuangan perusahaan. Adanya proses audit ini akan mempengaruhi ketepatan waktu penyediaan laporan keuangan. Lama atau delay dalam penyediaan laporan keuangan yang telah diaudit oleh auditor kepada pengguna laporan keuangan inilah yang dimaksudkan dalam audit delay.

Audit delay berdasarkan Ashton et al. (1987) merupakan rentang hari dari tanggal tutup buku tahun suatu perusahaan, yaitu 31 Desember sampai dengan tanggal penyelesaian laporan auditor independen. Menurut Dyer dan Mchugh (1975), audit delay atau biasa disebut dengan audit report lag dibedakan menjadi tiga yaitu preliminary lag, auditor's signature lag, dan total lag. Audit delay berdasarkan Abernathy et al. (2017) adalah jarak waktu dari akhir tahun fiskal suatu perusahaan sampai dengan tanggal laporan auditor dan sering dilihat sebagai pengukuran timeliness dari suatu laporan keuangan.

Alkhatib dan Marji (2012) mengatakan audit delay yang tepat waktu akan bermanfaat dalam pengambilan keputusan yang dilakukan pengguna laporan keuangan dan dapat mengurangi asimetri informasi antara perusahaan dengan pengguna laporan keuangan. Sebaliknya audit delay yang lama akan berdampak buruk bagi pemegang saham karena akan meningkatkan asimetri informasi dan menurunkan relevansi dari informasi dalam laporan keuangan yang dapat 
I Dewa Ayu Adelia Pratiwi dan Ketut Muliartha RM. Pengaruh...

mempengaruhi keputusan yang diambil oleh pemegang saham, sehingga akan mendorong perusahaan untuk melakukan pergantian auditor.

Penelitian yang dilakukan oleh Robbitasari (2013), Farid (2014), dan Pawitri (2015) menemukan bahwa audit delay berpengaruh secara signifikan terhadap pergantian auditor. Berbeda dari penelitian di atas, penelitian yang dilakukan oleh Ardianingsih (2014), dan Purwoningsih (2016) menemukan bahwa audit delay tidak berpengaruh secara signifikan terhadap pergantian auditor.

Penelitian ini dilakukan pada perusahaan manufaktur yang terdaftar di Bursa Efek Indonesia (BEI) pada rentang tahun 2015-2017. Peneliti memilih perusahaan manufaktur karena berdasarkan Badan Pusat Statistik (BPS) dikatakan bahwa sektor industri manufaktur merupakan leading sector dengan memberikan kontribusi terbesar terhadap Produk Domestik Bruto (PDB) Indonesia dibandingkan dengan sektor lainnya, yaitu sebesar 20 persen selama periode periode Triwulan I-III Tahun 2017. Selain itu sektor ini juga memberikan kontribusi ekonomi yang besar dalam transformasi struktur ekonomi bangsa dari sektor pertanian ke arah sektor industri. Hal ini juga dapat ditunjukkan dengan gambar berikut. 


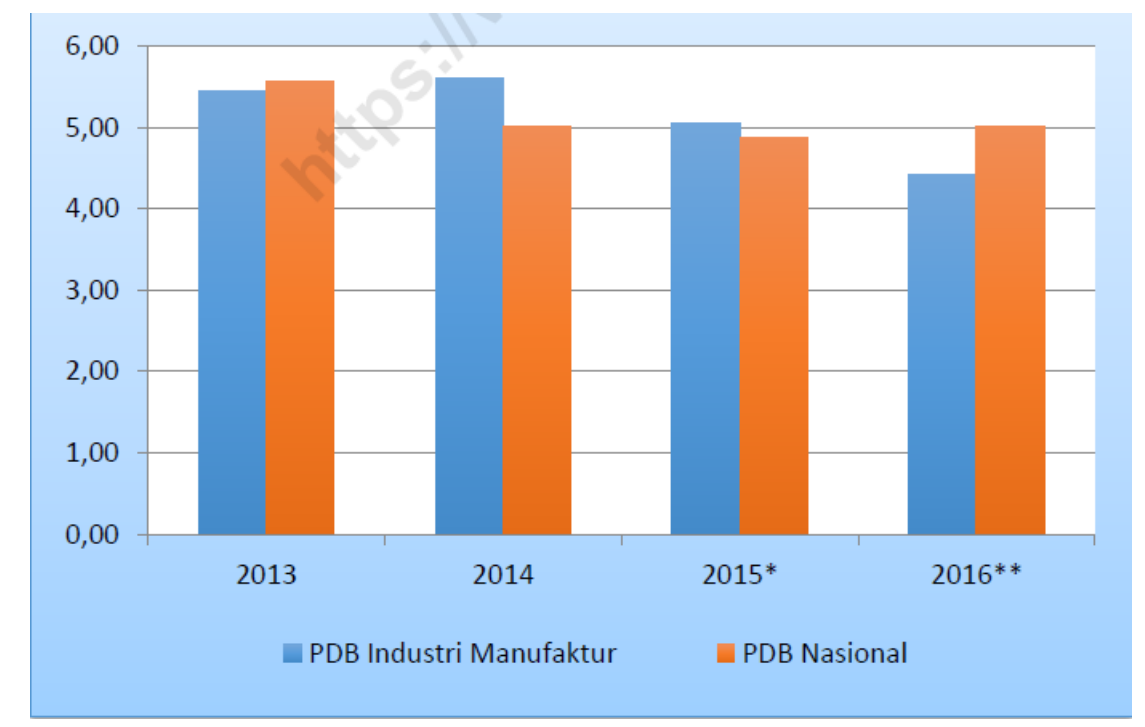

\section{Gambar 1.}

Pertumbuhan PDB Industri Manufaktur dan PDB Nasional Tahun 2013-2016 (dalam persen)

Sumber: Badan Pusat Statistik, 2017

Teori agensi berdasarkan Jensen dan Meckling (1976) memperlakukan pemegang saham sebagai principal dan manajemen sebagai agent, dimana pemegang saham memperkerjakan manajemen dalam menjalankan aktivitas perusahaan. Fasilitas perusahaan dan dana untuk operasi perusahaan disediakan oleh principal, sedangkan agent mengelola perusahaan dan memiliki kewajiban untuk meningkatkan nilai perusahaan dengan tujuan meningkatkan kemakmuran principal.

Dalam teori agensi sering timbul masalah agensi yang ada karena konflik kepentingan dan asimetri informasi antara principal dan agent. Eisenhardt (1989) mengatakan teori agensi didasari oleh 3 (tiga) asumsi yaitu asumsi mengenai sifat manusia yang mementingkan diri sendiri (self interest), keterbatasan rasionalitas (bounded rationatility), dan menghindari resiko (risk aversion); asumsi mengenai keorganisasian dan; asumsi dimana informasi dikatakan dapat diperjualbelikan. 
Berdasarkan teori agensi, Hudaib dan Cooke (2005) mengatakan dengan asumsi bahwa manusia itu memiliki sifat self interest, maka cenderung mendorong manajemen sebagai agent melakukan pergantian auditor dengan auditor yang sesuai dengan kondisi keuangan perusahaan, yaitu auditor dengan fee yang lebih rendah sehingga biaya audit yang dikeluarkan perusahaan tidak terlalu besar. Oleh karena itu, hipotesis penelitian ini adalah sebagai berikut.

$\mathrm{H}_{1}$ : Financial distress berpengaruh terhadap pergantian auditor.

Ukuran perusahaan yang besar menyebabkan manajemen memiliki tanggung jawab yang lebih tinggi kepada pemegang saham sehingga mendorong dilakukannya pergantian auditor oleh perusahaan dengan harapan auditor baru lebih berkualitas dibandingkan auditor lama dan memiliki independensi yang tinggi guna menghasilkan laporan keuangan yang memiliki kredibilitas tinggi sebagai bentuk tanggung jawab manajemen sebagai agent terhadap pemegang saham sebagai principles.

Berdasarkan Nazri et al. (2012) ukuran perusahaan yang lebih besar cenderung memiliki aktivitas perusahaan yang lebih kompleks yang dapat meningkatkan kesulitan pemegang saham sebagai principal dalam mengawasi tindakan manajemen.sebagai agent. Sehingga auditor dengan indepensi dan kualitas yang lebih tingi cenderung dipilih manajemen dalam melakukan pergantian auditor karena dianggap lebih mampu menjembatani kebutuhan principal dan agent. Oleh karena itu hipotesis penelitian ini adalah sebagai berikut.

$\mathrm{H}_{2}$ : Ukuran perusahaan berpengaruh positif terhadap pergantian auditor. 
Berdasarkan teori agensi, dimana ketika suatu perusahaan dengan audit delay yang lama sehingga terlambat dalam mempublikasikan laporan keuangannya, maka akan terdapat asimetri informasi antara pemegang saham sebagai principal dan manajemen sebagai agent. Selain itu, pemegang saham akan curiga bahwa terdapat masalah dalam perusahaan sehingga akan berpengaruh terhadap keputusan yang diambil pemegang saham dan harga saham perusahaan. Manajemen perusahaan sebagai agent cenderung akan melakukan pergantian auditor untuk menghindari audit delay yang lama dan kerugian yang dapat diterima perusahaan.

Sari dan Supadmi (2014) mengatakan bahwa audit delay yang melewati batas waktu yang diberikan BAPEPAM menyebabkan terlambatnya publikasi laporan keuangan yang dapat merugikan pemegang saham. Oleh karena itu audit delay yang semakin lama akan meningkatkan kemungkinan perusahaan dalam melakukan pergantian auditor (Stocken, 2000). Berdasarkan uraian di atas maka hipotesis penelitian ini adalah sebagai berikut.

$\mathrm{H}_{3}$ : Audit delay berpengaruh positif terhadap pergantian auditor.

\section{METODE PENELITIAN}

Penelitian ini dilakukan pada perusahaan manufaktur yang tercatat di Bursa Efek Indonesia (BEI) tahun 2015-2017. Obyek dalam penelitian ini adalah laporan tahunan perusahaan manufaktur di Bursa Efek Indonesia (BEI) periode 20152017. Berikut variabel yang diteliti pada penelitian ini yaitu financial distress, ukuran perusahaan, dan audit delay terhadap pergantian auditor. 
I Dewa Ayu Adelia Pratiwi dan Ketut Muliartha RM. Pengaruh...

Pada penelitian ini, auditor yang dimaksudkan dalam penelitian ini adalah akuntan publik terdaftar yang menandatangani laporan auditor independen perusahaan. Variabel pergantian auditor dalam penelitian ini diukur dengan menggunakan variabel dummy. Dimana akan diberikan nilai 1 apabila perusahaan melakukan pergantian auditor, dan akan diberikan nilai 0 apabila perusahaan tidak melakukan pergantian auditor.

Baldwin dan Mason (1983) mengatakan bahwa apabila suatu perusahaan tidak dapat memenuhi kewajiban finansialnya maka perusahaan tersebut dapat dikatakan mengalami financial distress. Sehingga dalam penelitian ini, financial distress diproksikan mengacu kepada penelitian Sulistiarini dan Sudarno (2012) yang menggunakan debt to equity ratio (DER). Adapun cara menghitungnya sebagai berikut:

DER $=\frac{\text { Total Utang }}{\text { Total Modal }} \times 100 \%$

Dalam penelitian ini, financial distress menggunakan variabel dummy, dimana jika perusahaan memiliki rasio DER diatas 100\% maka akan diberikan nilai 1 dan akan diberikan nilai 0 apabila rasio DER di bawah $100 \%$.

Penelitian ini menggunakan total aset untuk mengukur ukuran perusahaan karena total aset dianggap cenderung lebih stabil dan mampu menunjukkan ukuran perusahaan yang sesungguhnya apabila dibandingkan dengan proksi lainnya (Fitriani, 2014). Berikut rumus logaritma natural perubahan total aset:

$\operatorname{LnTA}=\ln (\mathrm{TAt}-0-\mathrm{TAt}-1)^{2}$ 
Keterangan :

LnTA = Logaritma natural dari perubahan total aset yang dikuadratkan

TAt- $0=$ Total aset pada tahun $\mathrm{t}$ saat dilakukannya pergantian auditor

TAt $-1=$ Total aset pada tahun $\mathrm{t}-1$ dilakukannya pergantian auditor

Audit delay sama dengan lama audit. Lama audit diukur dari tanggal tutup buku perusahaan sampai dengan tanggal ditandatangainya laporan auditor independen. Oleh karena itu dalam penelitian ini, pengukuran audit delay dihitung dari banyaknya hari dari tanggal laporan keuangan sampai dengan tanggal laporan auditor independen (Dwi A., 2015).

Populasi penelitian adalah perusahaan sektor manufaktur yang terdaftar di Bursa Efek Indonesia (BEI) tahun 2015-2017. Sampel dalam penelitan ditentukan menggunakan metode nonprobability sampling dengan teknik purposive sampling, menggunakan beberapa kriteria diantaranya: (1) Terdaftar di BEI secara berturut-turut pada tahun 2015-2017 dan mempubilkasikan laporan keuangan per 31 Desember secara lengkap pada tahun 2015-2017; (2) Tidak diaudit oleh auditor yang sama secara berturut-turut pada tahun 2015-2017; (3) Menyajikan informasi mengenai nama auditor yang menandatangani laporan auditor independen, tanggal ditandatanganinya laporan auditor independen, total aset, total utang dan total modal pada tahun 2015-2017; (4) Menggunakan satuan mata uang rupiah dalam laporan keuangan selama periode 2015-2017.

Teknik analisis data yang digunakan dalam penelitian ini adalah analisis regresi logistik karena variabel dependennya bersifat dummy. Analisis regresi logistik dalam penelitian ini digunakan untuk menguji $\mathrm{H}_{1}, \mathrm{H}_{2}$, dan $\mathrm{H}_{3}$ yaitu pengaruh financial distress, ukuran perusahaan, dan audit delay terhadap 
pergantian auditor. Adapun model regresi logistik dalam penelitian ini adalah sebagai berikut:

$\operatorname{Ln} \frac{\text { Switch }}{(1-\text { Switch })}=\alpha+\beta_{1} \mathrm{FD}+\beta_{2} \mathrm{UP}+\beta_{3} \mathrm{AD}+\varepsilon$

Keterangan:

$\alpha \quad$ : konstanta

Switch : Pergantian auditor

FD : Financial Distress

UP : Ukuran Perusahaan

AD : Audit Delay

$\varepsilon \quad$ : residual error

\section{HASIL DAN PEMBAHASAN}

Uji statistik deskriptif digunakan untuk mendeskripsikan variabel-variabel dalam penelitian ini yaitu pergantian auditor, financial distress, ukuran perusahaan, dan audit delay. Pengukuran statistik deskriptif yang diteliti dalam penelitian ini yaitu nilai minimum masing-masing variabel, nilai maksimum masing-masing variabel, nilai rata-rata masing-masing variabel dan standar deviasi masing-masing variabel. Hasil pengujian statistik deskriptif pada penelitian ini dapat dilihat pada Tabel 1.

Tabel 1. Hasil Uji Statistik Deskriptif

\begin{tabular}{lrrrrr}
\hline & N & Minimum & Maximum & \multicolumn{1}{c}{ Mean } & \multicolumn{1}{c}{ Std. Deviation } \\
\hline Switch & 168 & .00 & 1.00 & .5060 & .50146 \\
FD & 168 & .00 & 1.00 & .3274 & .47066 \\
UP & 168 & -1.057 & 1.608 & .15723 & .306542 \\
AD & 168 & 22.00 & 139.00 & 78.0893 & 15.13802 \\
Valid N (listwise) & 168 & & & & \\
\hline
\end{tabular}

Sumber: Data diolah, 2018

Berdasarkan Tabel 1. di atas variabel pergantian auditor memiliki nilai minimum sebesar 0 dan memiliki nilai maksimum sebesar 1 . Memiliki nilai rata- 
rata sebesar 0,50 dan memiliki nilai standar deviasi sebesar 0,50 yang menunjukkan pergantian auditor memiliki nilai rata-rata penyimpangan sebesar 0,50 .

Financial distress memiliki nilai minimum sebesar 0 dan memiliki nilai maksimum sebesar 1 . Memiliki nilai rata-rata sebesar 0,32 dan memiliki nilai standar deviasi sebesar 0,47 yang menunjukkan financial distress memiliki nilai rata-rata penyimpangan sebesar 0,47 .

Ukuran perusahaan memiliki nilai minimum sebesar -1,06 dan memiliki nilai maksimum sebesar 1,60 . Memiliki nilai rata-rata sebesar 0,16 dan memiliki nilai standar deviasi sebesar 0,31 yang menunjukkan ukuran perusahaan memiliki nilai rata-rata penyimpangan sebesar 0,31 .

Audit delay memiliki nilai minimum sebesar 22 dan memiliki nilai maksimum sebesar 139. Memiliki nilai rata-rata sebesar 78,09 dan memiliki nilai standar deviasi sebesar 15,14 yang menunjukkan audit delay memiliki nilai ratarata penyimpangan sebesar 15,14 .

Menilai kelayakan model regresi adalah uji yang dilakukan untuk melihat kecocokan antara data empiris dengan model regresi. Menilai kelayakan model regresi dapat dilihat dari tabel uji Hosmer dan Lemeshow, dimana apabila memiliki nilai signifikansi yang lebih besar dari 0,05 pada tabel uji Hosmer dan Lemeshow maka hipotesis nol diterima dan ini artinya model regresi dapat dikatakan cocok dengan data observasinya. Hasil Uji Hosmer dan Lemeshow dapat dilihat pada Tabel 2. 
Tabel 2.

\begin{tabular}{lcccc}
\multicolumn{4}{c}{ Uji Hosmer dan Lemeshow } \\
\hline Step & Chi-square & Df & Sig. \\
\hline 1 & 7.109 & 8 & .525 \\
\hline Sumber: & Data diolah, 2018 & & & \\
\hline
\end{tabular}

Dari Tabel 2. dapat dilihat bahwa dalam penelitian ini nilai signifikansi pada tabel uji Hosmer dan Lemeshow didapat sebesar 0,525 yang lebih besar dari 0,05, sehingga ini berarti model dapat dikatakan fit dengan data observasinya dan hipotesis nol diterima.

Menilai keseluruhan model dalam penelitian ini dilakukan untuk melihat kesesuaian keseluruhan model dengan data. Uji menilai keseluruhan model dilakukan dengan menbandingkan nilai antara -2 Log Likelihood (-2LL) pada awal dengan nilai -2 Log Likelihood (-2LL) pada akhir. Dimana model regresi dapat dikatakan baik atau dengan kata lain fit dengan data apabila terdapat penurunan nilai -2 Log Likelihood dari awal (Block Number $=0)$ ke akhir (Block Number = 1). Nilai -2 Log Likelihood dapat dilihat pada Tabel 3. Dan Tabel 4.

Tabel 3.

\begin{tabular}{|c|c|c|c|}
\hline \multicolumn{4}{|c|}{ Iteration History $($ Block Number $=0$ ) } \\
\hline \multirow{2}{*}{\multicolumn{2}{|c|}{ Iteration }} & $-2 \mathrm{Lc}$ & Coefficients \\
\hline & & likelihood & Constant \\
\hline \multirow[t]{2}{*}{ Step 0} & 1 & 232.874 & .024 \\
\hline & 2 & 232.874 & .024 \\
\hline
\end{tabular}

Menilai keseluruhan model dalam penelitian ini dilakukan untuk melihat kesesuaian keseluruhan model dengan data. Uji menilai keseluruhan model dilakukan dengan menbandingkan nilai antara -2 Log Likelihood (-2LL) pada awal dengan nilai -2 Log Likelihood (-2LL) pada akhir. Dimana model regresi dapat dikatakan baik atau dengan kata lain fit dengan data apabila terdapat 
penurunan nilai -2 Log Likelihood dari awal (Block Number $=0)$ ke akhir (Block Number = 1). Nilai -2 Log Likelihood dapat dilihat pada Tabel 3. Dan Tabel 4.

Tabel 4.

Iteration History (Block Number =1)

\begin{tabular}{|c|c|c|c|c|c|c|}
\hline \multirow{2}{*}{\multicolumn{2}{|c|}{ Iteration }} & \multirow{2}{*}{$\begin{array}{l}-2 \text { Log } \\
\text { likelihood }\end{array}$} & \multicolumn{4}{|c|}{ Coefficients } \\
\hline & & & Constant & FD & UP & AD \\
\hline \multirow[t]{4}{*}{ Step 1} & 1 & 225.884 & -1.107 & -.218 & 1.149 & .013 \\
\hline & 2 & 225.817 & -1.176 & -.228 & 1.294 & .014 \\
\hline & 3 & 225.817 & -1.178 & -.228 & 1.299 & .014 \\
\hline & 4 & 225.817 & -1.178 & -.228 & 1.299 & .014 \\
\hline
\end{tabular}

Hasil uji pada penelitian didapatkan nilai -2 Log Likelihood (-2LL) di awal $($ Block Number $=0)$ sebesar 232,874, dan nilai -2 Log Likelihood (-2LL) pada akhir (Block Number $=1$ ) adalah sebesar 225,817. Dapat dilihat nilai Likelihood (-2LL) yang mengalami penurunan pada penelitian ini berarti model regresi dapat dikatakan fit atau cocok dengan data.

Koefisien determinasi merupakan uji yang dilakukan untuk melihat seberapa besar variabel dependen mampu dijelaskan oleh variabel-variabel independen dalam penelitian ini. Besarnya nilai Nagelkerke $R$ Square, yang akan disajikan pada Tabel 5. akan menunjukkan hasil dari uji koefisien determinasi dalam penelitian ini.

Tabel 5.

Koefisien Determinasi

\begin{tabular}{lccr}
\hline Step & $\begin{array}{c}-\mathbf{2} \text { Log } \\
\text { likelihood }\end{array}$ & $\begin{array}{c}\text { Cox dan Snell } \\
\text { R Square }\end{array}$ & $\begin{array}{c}\text { Nagelkerke R } \\
\text { Square }\end{array}$ \\
\hline 1 & $225.817^{\text {a }}$ & .041 & .055 \\
\hline Sumber: Data diolah, 2018 & & &
\end{tabular}

Berdasarkan Tabel 5. di atas diperoleh nilai Nagelkerke $R$ Square dalam penelitian ini sebesar 0,055 yang memiliki arti sebesar 5,5 persen variabilitas 
variabel dependen dapat dijelaskan oleh variabel independen dalam penelitian ini, dan sisanya sebesar 94,5 persen tidak dapat dijelaskan oleh variabel independen dalam penelitian ini yang dijelaskan oleh variabel-variabel lain di luar penelitian.

Uji multikolinieritas dilakukan dalam penelitian ini untuk melihat apakah terdapat penyimpangan antar variabel-variabel independen pada model regresi dalam penelitian ini. Uji multikolinieritas dalam regresi logistik dapat dilihat dari nilai masing-masing variabel independen pada tabel matriks korelasi, yang dikatakan tidak adanya gejala multikolinieritas antar variabel-variabel independen pada penelitian ini apabila pada tabel matriks korelasi variabel independen mendapatkan nilai lebih kecil dari 0,8. Berikut akan disajikan Tabel 6 Matriks Korelasi.

Tabel 6. Matriks Korelasi

\begin{tabular}{|c|c|c|c|c|c|}
\hline & & Constant & FD & UP & AD \\
\hline \multirow[t]{4}{*}{ Step 1} & Constant & 1.000 & .082 & -.215 & -.968 \\
\hline & FD & .082 & 1.000 & .046 & -.220 \\
\hline & UP & -.215 & .046 & 1.000 & .107 \\
\hline & $\mathrm{AD}$ & -.968 & -.220 & .107 & 1.000 \\
\hline
\end{tabular}

Berdasarkan Tabel 6. dapat dilihat bahwa dalam penelitian ini semua nilai matriks korelasi antar variabel dependen lebih kecil dari 0,8. Ini berarti gejala multikolinieritas yang serius antar variabel dependen dalam penelitian ini tidak terjadi.

Nilai pada tabel matriks klasifikasi dalam penelitian ini menunjukkan kekuatan prediksi dari model regresi dalam memprediksi kemungkinan terjadinya pergantian auditor, yang disajikan Tabel 7. berikut. 
Tabel 7.

Matriks Klasifikasi

\begin{tabular}{|c|c|c|c|c|c|}
\hline & \multirow{3}{*}{\multicolumn{2}{|c|}{ Observed }} & \multicolumn{3}{|c|}{ Predicted } \\
\hline & & & \multicolumn{2}{|c|}{ Switch } & \multirow[b]{2}{*}{$\begin{array}{c}\text { Percentage } \\
\text { Correct }\end{array}$} \\
\hline & & & $\begin{array}{c}\text { tidak melakukan } \\
\text { pergantian } \\
\text { auditor }\end{array}$ & $\begin{array}{l}\text { melakukan } \\
\text { pergantian } \\
\text { auditor }\end{array}$ & \\
\hline \multirow[t]{3}{*}{ Step 1} & Switch & $\begin{array}{l}\text { tidak melakukan } \\
\text { pergantian auditor }\end{array}$ & 49 & 34 & 59.0 \\
\hline & & $\begin{array}{l}\text { melakukan pergantian } \\
\text { auditor }\end{array}$ & 41 & 44 & 51.8 \\
\hline & Overall & ercentage & & & 55.4 \\
\hline
\end{tabular}

Sumber : Data diolah, 2018

Berdasarkan Tabel 7. menunjukkan kekuatan dalam memprediksi dari model regresi dalam penelitian ini untuk memprediksi kemungkinan terjadinya pergantian auditor adalah sebesar 51,8\%. Hasil ini menunjukkan bahwa dengan model regresi dalam penelitian ini terdapat sebanyak 44 observasi yang diprediksi akan melakukan pergantian auditor dari total 85 observasi perusahaan yang melakukan pergantian auditor.

Model regresi logistik yang terbentuk dalam penelitian ini menghasilkan nilai koefisien regresi dan signifikansi dari variabel independen dalam penelitian ini. Berikut hasil uji regresi logistik yang ditunjukkan pada Tabel 8.

Tabel 8.

Hasil Uji Regresi Logistik

\begin{tabular}{lccc}
\hline \multicolumn{1}{c}{ Variabel } & B & Wald & Sig. \\
\hline Financial Distress & $-0,228$ & 0,434 & 0,510 \\
Ukuran Perusahaan & 1,299 & 4,695 & 0,030 \\
Audit Delay & 0,014 & 1,623 & 0,203 \\
Constant & & $-1,178$ & \\
\hline
\end{tabular}

Sumber: Data diolah, 2018

Berdasarskan Tabel 8. persamaan model regresi logistik yang dihasilkan adalah sebagai berikut: 
$\operatorname{Ln} \frac{\text { Switch }}{(1-\text { Switch })}=-1,178-0,228 \mathrm{FD}+1,299 \mathrm{UP}+0,014 \mathrm{AD}+\varepsilon$

Nilai konstanta dalam penelitian ini adalah sebesar -1,178, yang memiliki arti apabila seluruh variabel independen dianggap konstan maka kemungkinan dilakukannya pergantian auditor adalah sebesar $-1,178$.

Variabel financial distress (FD) memiliki nilai koefisien regresi logistik sebesar -0,23 yang berarti apabila perusahaan mengalami financial distress akan menyebabkan kemungkinan tidak dilakukannya pergantian auditor dengan asusmi variabel lainnya dianggap konstan. Nilai signifikansi yang didapat oleh variabel financial distress yang sebesar 0,51 berarti $\mathrm{H}_{1}$ ditolak yang artinya financial distress tidak berpengaruh terhadap pergantian auditor.

Variabel ukuran perusahaan (UP) memiliki nilai koefisien regresi logistik sebesar 1,30 yang memiliki arti kenaikan ukuran perusahaan akan menyebabkan kenaikan kemungkinan dilakukannya pergantian auditor dengan asusmi variabel lainnya dianggap konstan. Nilai signifikansi yang didapat oleh variabel ukuran perusahaan yang sebesar 0,30 dan nilai koefisien yang positif $(1,30)$ berarti $\mathrm{H}_{1}$ diterima yang artinya ukuran perusahaan berpengaruh positif terhadap pergantian auditor.

Variabel audit delay (AD) memiliki nilai koefisien regresi logistik sebesar 0,01 yang berarti semakin lama audit delay akan menyebabkan kemungkinan dilakukannya pergantian auditor semakin meningkat dengan asusmi variabel lainnya dianggap konstan. Nilai signifikansi yang didapat oleh variabel audit delay yang sebesar 0,20 berarti $\mathrm{H}_{1}$ ditolak yang artinya audit delay tidak berpengaruh terhadap pergantian auditor. 
Hasil dari pengujian analisis regresi logistik menunjukkan nilai signifikansi financial distress (FD) sebesar 0,51 yang berarti $\mathrm{H}_{1}$ ditolak yang juga memiliki arti bahwa financial distress tidak berpengaruh terhadap pergantian auditor. Hasil dari penelitian ini mendukung hasil penelitian yang dilakukan oleh Chadegani et al. (2011), Ali (2015), Pradhana (2015) dan Kusrina (2008).

Perusahaan dalam kondisi financial distress cenderung untuk tidak melakukan pergantian auditor karena apabila perusahaan terlalu sering melakukan pergantian auditor dapat menurunkan kepercayaan dari pemegang saham dan kreditur, dan akan menimbulkan anggapan yang negatif. Selain itu, analisis cost dan benefit dimana manajemen sebagai pihak agent akan membandingkan antara cost dan benefit yang akan didapat apabila suatu perusahaan melakukan pergantian auditor, maka perusahaan cenderung tidak melakukan pergantian auditor karena akan terdapat biaya start-up yang akan meningkatkan biaya agensi sehingga akan sulit untuk ditanggung oleh perusahaan yang mengalami financial distress (Sabeni dan Dwiyanti, 2014). Sedangkan, benefit yang didapatkan perusahaan belum tentu setara dengan cost yang dikeluarkan karena dengan melakukan pergantian auditor, akan memerlukan waktu untuk auditor baru dalam mengerti keadaan perusahaan dan menyesuaikan diri dengan lingkungan perusahaan.

Hasil dari pengujian analisis regresi logistik menunjukkan nilai signifikansi ukuran perusahaan (UP) sebesar 0,30 dan nilai koefisien yang positif $(1,30)$, maka $\mathrm{H}_{1}$ diterima dan ini berarti bahwa ukuran perusahaan berpengaruh positif terhadap pergantian auditor. Hasil penelitian ini sejalan dengan hasil 
I Dewa Ayu Adelia Pratiwi dan Ketut Muliartha RM. Pengaruh...

penelitian yang dilakukan oleh Fitriani (2014), Gharibi dan Geraeely (2016), Lestari dan Nuryatno (2018).

Ukuran perusahaan yang semakin besar maka semakin tinggi pula tanggung jawab manajemen terhadap pemegang saham, sehingga perusahaan cenderung melakukan pergantian auditor dengan memilih auditor yang memiliki independensi yang tinggi dan lebih berkualitas dengan harapan auditor tersebut dapat menghasilkan laporan keuangan yang memiliki kredibilitas yang tinggi sebagai bentuk pertanggungjawaban manajemen terhadap pemegang saham.

Apabila berlandaskan teori agensi, Nazri et al. (2012) mengatakan ketika ukuran perusahaan telah meningkat maka akan meningkatkan kompleksitas dari aktivitas perusahaan sehingga akan meningkatkan kesulitan pemegang saham sebagai principal dalam mengawasi tindakan manajer sebagai agent. Oleh karena itu manajemen sebagai agent cenderung melakukan pergantian auditor dan memilih auditor baru yang lebih besar dan memiliki kualitas dan independensi yang tinggi karena auditor yang lebih besar dianggap lebih mampu menjembatani kebutuhan principal dan agent.

Hasil dari pengujian analisis regresi logistik menunjukkan nilai signifikansi audit delay (AD) sebesar 0,20 yang berarti $\mathrm{H}_{1}$ ditolak yang juga memiliki arti bahwa audit delay tidak berpengaruh terhadap pergantian auditor. Hasil penelitian ini mendukung hasil penelitian Ardianingsih (2014), dan Purwoningsih (2016).

Audit delay yang lama namun belum melewati batas ketentuan dari BAPEPAM cenderung mendorong perusahaan untuk berpikir kembali dalam 
melakukan pergantian auditor. Hal ini karena apabila audit delay belum melewati batas ketentuan dari BAPEPAM informasi dalam laporan keuangan masih dapat dikatakan relevan untuk pengambilan keputusan yang dilakukan oleh pemegang saham. Selain itu, apabila dilakukan pergantian auditor, maka akan perlu waktu untuk auditor baru dalam mengerti keadaan perusahaan dan menyesuaikan diri dengan lingkungan perusahaan dan tidak ada jaminan bahwa auditor baru dapat melaksanakan pengauditan lebih cepat dibandingkan dengan auditor lama (Purwoningsih, 2016).

Penelitian ini menghasilkan simpulan mengenai bagaimana pengaruh financial distress, ukuran perusahaan, dan audit delay terhadap pergantian auditor. Hasil dari penelitian ini menjelaskan bahwa ukuran perusahaan berpengaruh positif terhadap pergantian auditor, sedangkan financial distress dan audit delay tidak berpengaruh terhadap pergantian auditor. Penelitian ini dapat menambahkan bukti empiris serta menambah wawasan mengenai financial distress, ukuran perusahaan, audit delay, dan pergantian auditor.

Hasil penelitian yang menunjukkan ukuran perusahaan berpengaruh positif terhadap pergantian auditor dapat memperkuat teori agensi bahwa ketika ukuran perusahaan telah meningkat maka kompleksitas dari aktivitas perusahaan juga akan meningkat sehingga akan meningkatkan kesulitan pemegang saham sebagai principal dalam memantau tindakan manajemen sebagai agent, dan manajemen cenderung melakukan pergantian auditor dan memilih auditor lebih besar yang dianggap memiliki kualitas dan independensi yang tinggi karena dianggap lebih mampu menjembatani kebutuhan principal dan agent. Namun dalam penelitian ini 
financial distress dan audit delay belum dapat menunjukkan dan menjadi acuan untuk memahami konflik kepentingan dalam teori agensi.

Penelitian ini diharapkan akan memberikan kontribusi positif bagi semua pihak khususnya pihak KAP atau akuntan publik, dan perusahaan. Bagi pihak KAP atau akuntan publik yaitu dengan lebih mempertimbangkan faktor-faktor yang mendorong manajemen perusahaan melakukan pergantian auditor, juga agar auditor selalu menjaga independensinya sehingga manajemen perusahaan tidak melakukan pergantian auditor secara sukarela. Selain itu, penelitian ini juga diharapkan dapat dijadikan referensi oleh manajemen perusahaan mengenai kebijakan yang akan diambil sehubungan dengan dilakukannya pergantian auditor.

\section{SIMPULAN}

Financial distress pada penelitian ini tidak ditemukan berpengaruh terhadap pergantian auditor perusahaan manufaktur yang terdaftar di Bursa Efek Indonesia selama periode 2015-2017, karena untuk melakukan pergantian auditor membutuhkan biaya yang besar di awal dan juga untuk menjaga kepercayaan dari pemegang saham dan kreditur. Ukuran perusahaan berpengaruh positif terhadap pergantian auditor pada perusahaan manufaktur yang terdaftar di Bursa Efek Indonesia selama periode 2015-2017, karena semakin besar ukuran perusahaan maka semakin besar pula tanggung jawab manajemen terhadap investor yang akan mendorong dilakukannya pergantian auditor dengan auditor dengan auditor yang lebih berkualitas dan memiliki kredibilitas yang tinggi. Audit delay tidak 
berpengaruh terhadap pergantian auditor perusahaan manufaktur yang terdaftar di Bursa Efek Indonesia selama periode 2015-2017, karena apabila audit delay belum melewati batas BAPEPAM yaitu 90 hari, maka perusahaan cenderung tidak melakukan pergantian auditor karena digantinya auditor akan membutuhkan waktu untuk auditor baru melakukan penyesuaian terhadap perusahaan dan mengerti keadaan perusahaan, dan juga belum tentu auditor baru dapat melaksanakan pengauditan secara tepat waktu.

Terdapat keterbatasan dalam penelitian ini dimana ditemukan pada hasil uji koefisien determinasi nilai pada Nagelkerke R Square sebesar 0.055, dimana ini menandakan hanya 5,5 persen pergantian auditor dapat dijelaskan oleh variabel independen dalam penelitian ini. Sehingga peneliti selanjutnya diharapkan untuk untuk menambahkan variabel-variabel independen lain yang belum diteliti dalam penelitian ini yang mungkin mempengaruhi pergantian auditor. Keterbatasan di atas mungkin juga disebabkan karena dalam penelitian ini hanya melakukan penelitian pada sektor manufaktur. Oleh karena itu, diharapkan penelitian selanjutnya untuk melakukan penelitian pada sektor-sektor lain untuk meningkatkan pengetahuan mengenai pergantian auditor di Indonesia.

\section{REFERENSI}

Abernathy, J. L., Barnes, M., Stefaniak, C., \& Weisbarth, A. (2017). An International Perspective on Audit Report Lag: A Synthesis of the Literature and Opportunities for Future Research. International Journal of Auditing, 21(1), 100-127. https://doi.org/10.1111/ijau.12083

Abidin, S., Ishaya, I. V., \& M-nor, M. N. (2016). The Association between Corporate Governance and Auditor Switching Decision. International Journal of Economics and Financial Issues, 6(7), 77-80. 
Ali, K. H. (2015). Determinants of Auditor Switching in Bahraini'S Listed Companies - an Empirical Study. European Journal of Accounting, Auditing and Finance Research, 3(11), 73-99. https://doi.org/10.1017/CBO9781107415324.004

Alkhatib, K., \& Marji, Q. (2012). Audit reports timeliness: Empirical evidence from Tunisia. Procedia - Social and Behavioral Sciences, 62, 1342-1349. https://doi.org/10.1080/23311975.2016.1195680

Ardianingsih, A. (2014). Pengaruh Audit Delay dan Ukuran KAP Terhadap Audit Switching: Kajian dari Sudut Pandang Klien. Pena Jurnal Ilmu Pengetahuan Dan Teknologi, 27(1).

Ashton, R. H., Willingham, J. J., \& Elliott, R. K. (1987). An Empirical Analysis of Audit Delay. Journal of Accounting Research, 25(2), 275-292.

Financial Distress the Case of Massey Ferguson. The Journal of Finance, 38(2), 505-516. https://doi.org/10.2307/2327985.

Blouin, J., Grein, B. M., \& Rountree, B. R. (2007). An analysis of forced auditor change: The case of former Arthur Andersen clients. Accounting Review, 82(3), 621-650. https://doi.org/10.2308/accr.2007.82.3.621.

Chadegani, A. A., Mohamed, Z. M., \& Jari, A. (2011). The Determinant Factors of Auditor Switch among Companies Listed on Tehran Stock Exchange. International Research Journal of Finance and Economics, 80(80), 158-168.

Dwi A., C. (2015). Pengaruh Kepemilikan Manajemen , Dan Reputasi Kap Terhadap Pergantian Dan Reputasi Kap Terhadap Pergantian Auditor Secara Voluntary (Studi Empiris Perusahaan Manufaktur yang Terdaftar di Bursa Efek Indonesia Periode 2008-2013).

Dyer IV, J. C., \& Mchugh, A. J. (1975). The Timeliness of the Australian Annual Report times. Journal of Accounting Research, 13(2), 204-219.

Eisenhardt, K. M. (1989). Building Theories from Case Study Research. The Academy of Management Review, 14(4), 532-550. https://doi.org/10.2307/258557

Farid, Z. (2014). Faktor-Faktor yang Mempengaruhi Pergantian Kantor Akuntan Publik Pada Perusahaan Go Public Di Indonesia (Studi Empiris pada Perusahaan Manufaktur yang Terdaftar di Bursa Efek Indonesia Tahun 20072012). Diponegoro Journal of Accounting, 3(4), 73-78.

Fitriani, N. A. (2014). Analisis Faktor-Faktor Yang Mempengaruhi Voluntary 
Auditor Switching Di Perusahaan Manufaktur Indonesia. Diponegoro Journal of Accounting, 3(2), 1-13.

Gharibi, A. K., \& Geraeely, M. S. (2016). Investigating the effective factors on changing auditor: Evidences of Iranian firms. Problems and Perspectives in Management, 14(3), 401-406. https://doi.org/10.21511/ppm.14(3-si).2016.14

Hudaib, M., \& Cooke, T. E. (2005). The Impact of Managing Director Changes and Financial Distress on Audit Qualification and Auditor Switching. Journal of Business Finance \& Accounting, 32(9), 1703-1739.

Ika S., S. (2014). Faktor-Faktor Yang Berpengaruh Terhadap Auditor Switching (Studi Empiris pada Perusahaan Manufaktur yang Terdaftar di Bursa Efek Indonesia Periode Tahun 2010-2013).

Jensen, M. C., \& Meckling, W. H. (1976). Theory of Firm: Managerial Behavior, Agency Costs and Ownership Structure. Journal of Financial Economics, 3(4), 305-360. Retrieved from http://ssrn.com/abstract=94043http://hupress.harvard.edu/catalog/JENTHF.ht $\mathrm{ml}$

Khasanah, I., \& Nahumury, J. (2013). The factors affecting auditor switching in manufacturing companies listed in Indonesia Stock Exchange (BEI). Journal of Accounting, 3(2), 203-212. https://doi.org/10.14414/tiar.13.030210

Kristiawan, A. (2017). Analisis Pengaruh Ukuran KAP, Opini Audit, Ukuran Perusahaan, dan Profitabilitas Perusahaan Terhadap Auditor Switching.

Kusrina, B. L. (2008). Analysis of Factors Affecting Auditor Switching, 13(I), 2463-2470.

Lestari, S. Y., \& Nuryatno, M. (2018). Factors Affecting the Audit Delay and Its Impact on Abnormal Return in Indonesia Stock Exchange. International Journal of Economics and Finance, 10(2), 48. https://doi.org/10.5539/ijef.v10n2p48

Nasser, A. T. A., Wahid, E. A., Nazri, S. N. F. S. M., \& Hudaib, M. (2006). Auditor-client relationship : The case of audit tenure and auditor switching in Malaysia. Managerial Auditing Journal, (May 2014), 724-737. https://doi.org/10.1108/02686900610680512

Nazri, S. N. F. S. M., Smith, M., \& Ismail, Z. (2012). The impact of ethnicity on auditor choice: Malaysian evidence. Asian Review of Accounting, 20(3), 198-221. https://doi.org/10.1108/13217341211263265 
Pawitri, N. M. P. (2015). Pengaruh Audit Delay, Opini Audit, Reputasi Auditor dan Pergantian Manajemen Pada Voluntary Auditor Switching. E-Jurnal Akuntansi Universitas Udayana, 10(1), 214-228.

Pradhana, M. A. B. (2015). Pengaruh Audit Fee, Going Concern, Financial Distress, Ukuran Perusahaan, Pergantian Manajemen Pada Pergantian Auditor. Jurnal Akuntansi Universitas Udayana, 11.3, 713-729.

Purwoningsih, R. B. (2016). Pengaruh Opini Audit Going Concern, Audit Delay, Aktivitas Komite Audit, Pertumbuhan Perusahaan Terhadap Pergantian Auditor dengan Keahlian Keuangan dan Akuntansi Komite Audit Sebagai Variabel Moderasi. Jurnal Akuntansi Universitas Muhammadiyah Yogyakarta.

Robbitasari, A. P. (2013). Pengaruh Opini Audit Going Concern, Kepemilikan Institusional dan Audit Delay Pada Voluntary Auditor Switching. E-Jurnal Akuntansi Universitas Udayana 5.3, 3, 652-665.

Sabeni, A., \& Dwiyanti, R. M. E. (2014). Faktor-Faktor yang Mempengaruhi Auditor Switching. Diponegoro Journal of Accounting, 3(3), 2337-3806.

Sari, M. M. R., \& Supadmi, N. L. (2014). Gender Komite Audit dan Audit Delay. Jurnal Ilmiah Akuntansi Dan Bisnis, 9(2), 65-72.

Sinarwati, N. K. (2010). Mengapa Perusahaan Manufaktur yang Terdaftar di BEI Melakukan Pergantian Kantor Akuntan Publik? PhD Proposal, 1, 1-20. https://doi.org/10.1017/CBO9781107415324.004

Sinason, D. H., Jones, J. P., \& Waller Shelton, S. (2001). An Investigation of Auditor and Client Tenure. American Journal of Business, 16(2), 31-40. https://doi.org/10.1108/19355181200100010

Statistik, B. P. (2017). Perkembangan Indeks Produksi Industri Manufaktur 20152017. Retrieved from www.bps.go.id

Stocken, P. C. (2000). Credibility of Voluntary Disclosure, 31(2), 359-374. https://doi.org/10.1086/678128.

Sulistiarini, E., \& Sudarno. (2012). Analisis Faktor-Faktor Pergantian Kantor Akuntan Publik (Studi Empiris Pada Perusahaan Manufaktur di Bursa Efek Indonesia Periode 2006-2010 ). Diponegoro Journal of Accounting, 1(2), 112.

Sumadi, K. (2011). Mengapa Perusahaan Melakukan Auditor Switch? Jurnal Ilmiah Akuntansi Dan Bisnis, 6(1), 1-11. 
ISSN: 2302-8556

E-Jurnal Akuntansi Universitas Udayana

Vol.26.2.Februari (2019): 1048-1074

Widiawan, W. (2011). Faktor-Faktor yang Mempengaruhi Pergantian Kantor Akuntan Publik ( Studi Empiris pada Perusahaan Keuangan yang Terdaftar di Bursa Efek Indonesia Tahun 2003-2008 ). Universitas Diponegoro.

Widyanti, A. A. S. I. (2016). Reputasi Auditor Sebagai Pemoderasi Pengaruh Financial Distress Pada Auditor Switching. Jurnal Akuntansi Universitas Udayana, 16.3, 1800-1828. 